\title{
THE METABOLISM OF CHOLESTEROL
}

\author{
By B. Lewis, Ph.D., M.D.(Cape Town) \\ Formerly Research Officer, Clinical Nutrition Research Unit, Department of Medicine, University of Cape Town \\ C. F. Adams Travelling Fellow for 1959
}

The biochemistry of the steroids is of unique interest; no other group of relatively simple substances plays so versatile a role in biology. On the one hand are many highly potent steroids occurring in minute quantities and often with clearly-defined functions, e.g. sex hormones, corticosteroids, the vitamins $\mathrm{D}$ and the cardiac glycosides. In sharp contrast are certain sterols, exemplified in the animal kingdom by cholesterolfamiliar, abundant, readily determined, yet singularly obscure in their physiological significance. The structural formulae of some important steroids are shown in Fig. I.

\section{Functions of Cholesterol}

In some restricted fields the functions of cholesterol are at least partly recognized. It is important in the biosynthesis of several steroid hormones (Heard et al., 1956; Hechter and Pincus, 1954; Roberts and Szego, 1955), and is present in high concentration in the adrenal cortex and corpus luteum; it is readily synthesized from acetate in these organs. Cholesterol is a precursor of the corticosteroids, androgens and progesterone. ACTH causes rapid depletion of adrenocortical cholesterol; perfusion studies have shown that one action of this hormone is to accelerate the conversion of cholesterol to $2 \mathrm{I}$-carbon atom intermediaries in corticosteroid synthesis, e.g. $\triangle^{5}$ pregnenolone (Stone and Hechter, 1954), and to the androgens. However, cholesterol is not an obligatory intermediary in the formation of steroid hormones: some preparations of adrenocortical tissue convert labelled acetate to such hormones without the appearance of labelled cholesterol (Heard et al., 1956; Stone and Hechter, 1954, Ungar and Dorfman, 1953). Nor are the oestrogens synthesized from cholesterol (Heard and O'Donnell, I954), acetate is utilized in the formation of these aromatic, i.e. benzenecontaining compounds, but cholesterol is not an intermediary.

Other probable functions of cholesterol include the synthesis of vitamin $D_{3}$. The skin contains a higher proportion of 7 -dehydrocholesterol than
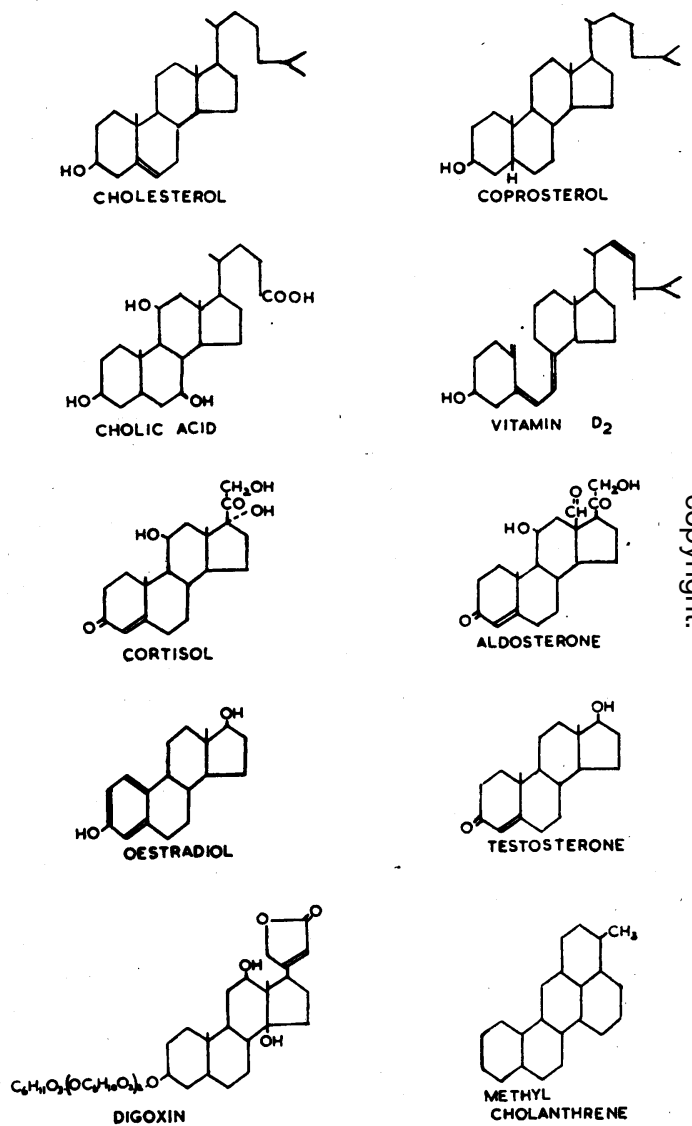

FIG. I.-Structural formulae of some steroids of biological significance.

other tissues (Rosenberg, I945); this sterol is thought to be derived from cholesterol, and gives rise to the active vitamin under the influence of ultra-violet light. Cholesterol esters, together with sphingomyelin, form a major constituent of 0 the myelin sheaths of nerve fibres, where these lipids may have an insulating function necessary at least for saltatory conduction. Cholesterol plays an important role in the synthesis of the bile acids. The small amount of cholesterol present in 
all animal cells is of unknown significance; the cholesterol and phosphatide content of rat skeletal muscle is increased by exercise (Bloor, 1940), suggesting that in this site, too, the sterol may be of functional importance.

\section{The Plasma Cholesterol}

The past decade has seen a spate of investigations into the physiology of the circulating cholesterol and its likely relationship to atherosclerosis; but the interpretation of changes in plasma level (both total and fractionated) is still more often speculative than factual. The plasma cholesterol arises largely by endogenous synthesis, but dietary cholesterol contributes a varying proportion. The cholesterol of plasma exchanges with most tissues, at widely differing rates, both in man and in experimental animals (Gould, 1954; Eckles et al., 1955). One determinant of the rate of exchange of cholesterol between plasma and cells is the availability of the specific cholesterol-binding proteins (Eckles et al., 1955).

What is the physiological role of the cholesterol in the blood? There is no cogent evidence for the textbook statement that it plays a part in fatty acid transport; against this hypothesis is the fact that the fatty acids of plasma cholesterol esters differ considerably from those of depot and liver fat. About two-thirds of the plasma cholesterol (the ester fraction), is combined with fatty acids. These include a large proportion of highly unsaturated acids, the mean iodine value in man being 160 (Bloor et al., 1938). Linoleic and arachidonic acids (which have two and four double bonds respectively) are prominent in plasma cholesterol esters (Kelsey and Longenecker, 194I ; Lewis, I $958 \mathrm{a}$ ); on the other hand, the fats of adipose and liver tissue contain mainly palmitic and stearic acids, with no double bonds, and oleic acid which has one.

Cholesterol is rapidly synthesized in the liver, which organ is the main source of the plasma cholesterol (Friedman et al., I95I) as well as the site of its esterification (Friedman and Byers, 1955). But its synthesis is accomplished (at various rates) by every tissue which has been tested except mature nervous tissue; even the arterial wall can incorporate acetate into cholesterol (Werthessen et al., 1954). The brain synthesizes cholesterol only until myelination is complete (Srere et al., 1950). Its presence in the blood does not necessarily indicate transport from a site of synthesis to one of utilization.

\section{Cholesterol Transport}

Cholesterol is only minutely soluble in water, and its presence as a clear solution in plasma is due to its combination with $\alpha \mathrm{I}-$ and $\beta \mathrm{I}$-globulins in the $\alpha$ - and $\beta$-lipoproteins. These complex proteins also contain phosphatide, some triglyceride, and water of hydration. The protein lipid linkage is poorly understood; its partial cleavage by freezing (McFarlane, 1942) suggests that water (40 per cent. by weight of $\beta$-lipoprotein) plays a part (Oncley et al., I950), but another interpretation is that a 'shell' of water surrounds the lipoprotein molecule. Secondly, cholesterol can be removed from lipoprotein by certain extraction procedures, leaving the phosphatide still bound to globulin (Lovern, 1954); the converse has not been reported. It would appear that cholesterol is to some extent a 'passenger,' attached relatively loosely to the more stable (and more water-soluble) protein-phosphatide complex. Hence, a highserum cholesterol/phosphatide ratio, which is often observed in patients with atherosclerosis (Morrison, 1952), may conceivably be associated with diminished 'stability' of the lipoprotein solution.

The $\alpha$-lipoprotein contains some 39 per cent. by weight of lipid (Oncley et al., I950; Oncley et al., I949); its concentration is relatively constant in health and disease. On the other hand, $\beta$-lipoprotein contains about 77 per cent. of lipid, and is much more variable in amount. It comprises several components of different densities as measured by ultracentrifugation; those of lowest density are important in triglyceride transport. In some types of liver disease, qualitative abnormalities in serum lipoproteins have been reported, low protein content being a feature (Russ et al., 1956). The other category of circulating lipid is the chylomicron fraction, visible particles containing a preponderance of triglyceride and little protein ( $\alpha 2$-globulin); these extremely low-density lipoproteins appear during the absorption of ingested fat, render the plasma lactescent, and are removed by the complex 'clearing system' (Andersson and Fawcett, 1950; Anfinsen, 1954; Bergström and Borgström, 1956; Friedman et al., 1956).

The relevance of this system to cholesterol metabolism is not yet clear. It has been invoked to explain the hyperlipaemia and hypercholesterolaemia of the nephrotic syndrome. Rosenman et al. (1957) have shown that in experimental nephrosis in rats the fall in serum albumen is followed by a rapid rise in serum triglyceride and a slower elevation of cholesterol and phosphatide levels. In view of the importance of the plasma albumen in transporting the fatty acids released from chylomicrons by the clearing process, it was suggested that the changes in plasma lipids are primarily due to hypo-albumenaemia causing a bottleneck in lipaemia clearance. 


\section{Synthesis, Catabolism and Excretion of Cholesterol}

As has been stated, most animal and human tissues which have been studied, can synthesize cholesterol (Friedman et al., 1955; Werthessen et al., i954). In liver homogenates labelled acetate has been incorporated into cholesterol within Io minutes (Schwenk et al., 1955). The intracellular site of cholesterol synthesis has been investigated by ultracentrifugation of liver homogenates; both the soluble fraction and the large microsomes appear to be necessary (Bucher and McCarrahan, I955).

The stages in the biosynthesis of cholesterol have largely been identified. Cornforth and Popjak (1958), Friedman and Byers (1956) and Bloch (I95I) have provided valuable reviews of this topic. Acetate, in its metabolically-active form acetyl coenzyme A may be regarded as the starting point, itself arising from carbohydrate, fat and protein catabolism (Fig. 2). Two molecules condense to form aceto-acetyl coenzyme A; this substance is important as the end-product of $\beta$-oxidation of fatty acids. Condensation with a third molecule of acetate yields the first of a series of branched-chain acids including the 5 -carbon atom $\beta, \beta$-dimethyl acrylic acid. These branchedchain acids may also be derived from aminoacids (Coon, 1955). The 6-carbon atom mevalonic acid is an important intermediary (Tavormina $e t$ al., 1956); it is probable that (after losing one carbon atom), six of the resulting molecules condense to form the hydrocarbon squalene ( 30 carbon atoms) (Cornforth et al., 1958). Cyclization (the formation of ' cross-linkages') converts this linear molecule into a condensed ring system; there is good evidence that lanastadienol is directly formed in this process. Loss of three carbon atoms and rearrangement of the ring structure subsequently yields cholesterol.

Many experiments have been published which deal with factors affecting the rate of synthesis of cholesterol. Friedman et al. (1956) has analysed the difficulties in the tracer techniques involved.

About 70 per cent. of ingested cholesterol is absorbed (Karvinen et al., 1957). It is transported in the lacteals (Biggs et al., 195I) and appears in the plasma as low-density chylomicra containing phosphatide and trighyceride but very little protein (Robinson, 1955; Page et al., 1953). These chylomicra are rapidly deposited in the liver, at least in the rat (Byers et al., 1953); phagocytosis by hepatic reticulo-endothelial cells may contribute to this (Feigenbaum et al., 1954). However, Messinger et al. (1950) and Keys (1952a) found that the serum-cholesterol level in man is virtually unaffected by the dietary cholesterol intake. Morris et al. (1957) found

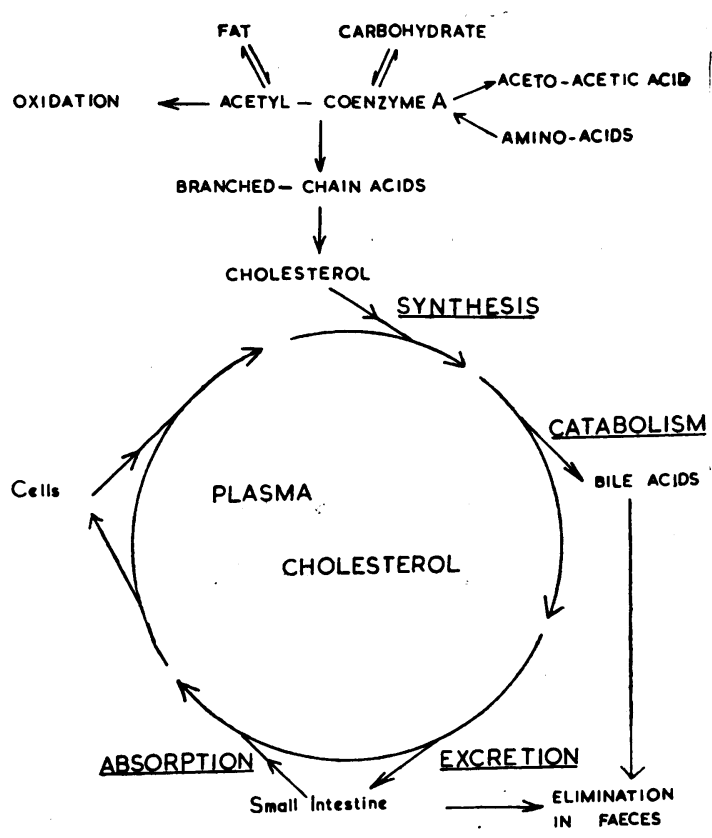

FIG. 2.-Variables influencing the serum-cholesterol level.

20 to 33 per cent. of the serum cholesterol in rat to be of dietary origin when the cholesterol intake was low; the percentage rose to 74 to 90 per cent. when large quantities of cholesterol were fed. Gould et al. (I953) observed that cholesterol feeding depressed the synthesis of this sterol; the lack of effect of dietary cholesterol on the serum level in man may therefore be due to a homeostatic diminution of endogenous synthesis.

The main end-products of cholesterol metabolism are the bile acids (Bloch et al., I943; Bergström, 1952), largely glycocholic acid in man (Siperstein and Murray, I955). After administration of ${ }^{14} \mathrm{C}$-labelled cholesterol, excretion of radioactivity takes place almost exclusively in the faeces; a trace appears in the urine (perhaps as steroid hormone metabolites). Only the terminal three carbon atoms of the cholesterol side chain are $\frac{D}{2}$ excreted as carbon dioxide. Siperstein and Murray (1955) administered cholesterol-4-14 $\mathrm{C}$ $\mathrm{N}$ intravenously to a man with a bile fistula; 98 per cent. of the radio-activity appeared in the bile, and only I.3 per cent. in the acholic faeces. Over 80 per cent. of the radio-activity in faeces is in the acid fraction, probably in the form of ketonic bile acids arising from bacterial oxidation of cholic acid in the colon. Cook et al. (r955) administered cholesterol to rats and showed increased faecal excretion of organic acids, probably ketonic bile acids.

The liver is the chief site of cholesterol cata- 
bolism, and several stages in the reaction sequence are known. In mouse liver cells the mitochondria are the organelles responsible (Fredrickson, 1956). Liver tissue is not unique in its ability to convert cholesterol to bile acid (Kendall, I958). It is important to note that $i t$ has not been proved that bile acids can be synthesized only from cholesterol (Bergström and Borgström, 1956).

In man, the principal faecal sterols are cholesterol and its saturated derivatives, coprosterol and cholestanol. Much of the cholesterol is secreted by the small intestine; a variable amount is derived from dietary cholesterol, and relatively little is contributed by the bile. Plant sterols are only slightly absorbed (Cook et al., I955): dietary sitosterol, for example, appears in the faeces, largely as sitocoprosterol.

Cholesterol absorption takes place in the small intestine. Isolated rat intestine absorbs both free and esterified cholesterol against a concentration gradient (Smith et al., 1958). This process is facilitated by bile salts, partly at least due to their emulsifying property. Although pancreatic juice contains an enzyme which promotes esterification of cholesterol, the pancreas has little influence on the overall rate of cholesterol absorption. The esterifying enzyme appears to exert its action in the intestinal mucosa (Smith et al., 1958). The ingestion of unsaturated oils does not suppress cholesterol absorption (Karvinen et al., 1954) corn-oil fatty acids, in fact, increase it (Kim and Ivy, 1952).

\section{Factors Affecting the Serum-cholesterol Level}

The concentration of cholesterol in the blood shows wide physiological variations, both from subject to subject and from time to time in any one individual. Single determinations in a given subject are likely to be misleading. Differences in analytical technique may also contribute to difficulties in interpretation. Standard textbooks describe the influence of age, sex, pregnancy, climate, time of day and emotional changes on serum-cholesterol levels, though Lindholm (1956) has recently critically assessed some of these variables. Keys et al. (1950) has analysed a large number of samples and reported prevailing values in various age-groups. As depicted in Fig. 2, the concentration of cholesterol in plasma is the resultant of several processes. Of the numerous variables influencing these, only diet and the endocrine system will be reviewed, for these are currently the subject of most intensive research.

\section{Diet}

Ahrens (1957) has recently provided a valuable review of the effect of diet on serum lipids. In rats, fasting decreases cholesterol synthesis (van
Bruggen et al., 1952), and the serum level tends to fall; carbohydrate feeding increases the rate of incorporation of acetate into cholesterol in liver slices (Hill et al., 1955). Many dietary saturated fats elevate the serum-cholesterol level (Keys, 1952b; Bronte-Stewart et al., 1956). It has been assumed that the mechanism is one of increased cholesterol synthesis from aceto-acetate derived from $\beta$-oxidation of the fatty acids. However, coconut fat feeding (which regularly elevates serum-cholesterol levels), does not accelerate the incorporation of acetate into cholesterol (Wód and Migicofsky, 1958). Another possibility has been raised by Hellman et al. (1957) who fed various fats for long periods to a patient with hypercholesterolaemia, then administered cholesterol $-4^{-14} \mathrm{C}$. They measured the faecal excretion of ${ }^{14} \mathrm{C}$, and ascribed the rising serum-cholesterol levels during butter-oil feeding to diminished intestinal excretion of cholesterol and its end-products.

Reduction of the serum-cholesterol level by certain dietary unsaturated fats is unlikely to be due to diminished synthesis of this sterol: cottonseed oil (Whitney and Roberts, 1955), linoleic acid (Merrill, 1958), corn oil and oleic acid (Wood and Migicofsky, 1958) increase hepatic cholesterol synthesis in the rat. Nor do such oils decrease cholesterol absorption (Karvinen et al., 1954). Hellman et al. (1957) have invoked an increase in intestinal excretion of cholesterol during corn-oil feeding as the mechanism. The importance of cholesterol catabolism has been suggested by recent observations on bile acid excretion: in short-term, transient-state experiments (Gordon et al., 1957a; Gordon et al., I957b), the faecal bile acid excretion was found to increase when sunflowerseed oil was fed, to an extent I i 5 per cent. of that necessary to account for the cholesterol leaving the circulation. In subjects with bile fistulae, similarly, cholic acid secretion was markedly increased by sunflowerseed-oil feeding before the serum cholesterol commenced to fall (Lewis, I $958 \mathrm{~b}$ ). Cholic acid secretion, which is an index of the rate of catabolism of cholesterol, was also increased by intravenous infusion of an emulsion of cottonseed oil. These findings suggest that certain dietary unsaturated fats reduce the serum cholesterol by increasing the rate of catabolism of this sterol, at least over short periods of time. Byers and Friedman (1958) have provided striking confirmation of this view by means of animal experiments; they administered walnut oil (which is highly unsaturated) to normal rats, then cannulated the bile ducts and showed increased cholic acid secretion. Evidence was obtained for increased cholesterol turnover on feeding this oil. In our studies, administration of a saturated fat did not affect bile acid output. 
Relationship of Highly-unsaturated Fatty Acidsto Cholesterol Metabolism

While oleic and saturated fatty acids are readily formed in the body it is thought that acids with two or more double bonds (e.g. linoleic acid) cannot be synthesized to an important extent by mammalian tissues (Lipsky et al., 1957; Reid, 1955; Reiser, 1950); certain polyunsaturated acids can, however, be interconverted (Rieckenhoff et al., 1949). Though it has recently been demonstrated that human erythrocytes can synthesize linoleic and arachidonic acids from acetate (James et al., 1957) it has yet to be shown (in the intact animal) that requirements can be met by endogenous synthesis. Linoleic and arachidonic acids behave as vitamins (' essential fatty acids') in the nutrition of several animal species (Burr and Burr, 1929; Deuel, 1955); there is little cogent evidence that this applies to man, but skin lesions have been reported in infants on diets grossly deficient in these acids (Hansen et al., 1958). Unsaturated acids are prominent in all oils which have the property of reducing serum-cholesterol levels.

When the intake of essential fatty acids by certain animals is restricted, the deficiency syndrome may be precipitated by feeding a saturated fat (Melnick and Deuel, 1954) or cholesterol (Peifer and Holman, 1955), or by producing hypercholesterolaemia by inducing hypothyroidism or alloxan diabetes.

At the cellular level, the interplay of fatty acids with cholesterol metabolism was shown in a fascinating study by Rutstein et al. (1958). These workers employed cultures of cells grown from human intima obtained during operations for resection of coarctation of the aorta. When cholesterol was present in the medium, intracellular lipid deposition occurred; this was accentuated by the addition of stearic acid (saturated) but was diminished by linolenic acid (three double bonds), an effect being observed with as little as $5 \mu \mathrm{g}$. per cent. of the latter acid.

Highly unsaturated fatty acids are present in a remarkable concentration in intracellular organelles (Kretchmer and Barnum, I95I) and as part of the 'structural lipid' are likely to be of functional importance. Availability of such acids may be a limiting factor in some of the metabolic processes occurring in these structures, conceivably including the conversion of cholesterol to bile acids.

The cholesterol esters of plasma contain a preponderance of unsaturated fatty acids (Bloor $e t$ al., 1938; Kelsey and Longenecker, 194I; Lewis, 1958a). Their fatty acid composition is influenced by diet: the iodine value, a measure of unsaturation, decreases when a fat-free diet or one rich in saturated fat is administered (Kinsell et al., 1958; Lewis, 1958a). Feeding certain unsaturated oils rapidly increases the iodine value to a figure far higher than that of the oil itself; dietary sun- $\frac{3}{0}$ flower-seed oil appears to increase the degree of ${ }_{C}^{\mathcal{Q}}$ unsaturation of plasma cholesterol ester before $\rightarrow$ the plasma cholesterol falls (Lewis, 1958a). This may mean that some cholesterol esters are moreo readily catabolized than others. Esters obtainedo from rabbits fed an unsaturated fat are more readily $\overline{\bar{c}}$. hydrolysed than those from animals receiving $a \stackrel{\infty}{\varnothing}$ saturated fat (Curran, 1956). Essential fatty acido deficiency in the rat leads to deposition of choles- ${ }^{\infty}$ terol and fat in the liver (Alfin-Slater et al., 1954).. Under these conditions, furthermore, much of the $\vec{\overrightarrow{ }}$ liver cholesterol becomes esterified with saturated ${ }_{\sigma}^{\omega}$ fatty acids in place of oleiclacid (Achaya et al., 1955).

The proportion of saturated to unsaturated fat 3 . in the diet has been invoked as an important aetio- $\omega_{n}$ logical factor in coronary atherosclerosis (BronteStewart et al., 1956). While it is well established that the nature of the dietary fat influences the N level of cholesterol in the blood, current studies on $\infty$ plasma cholesterol esters suggest that qualitative $\stackrel{\circ}{-}$ changes may also be important. In a relatively small survey, plasma cholesterol ester composition $\frac{\text { ? }}{0}$ was compared in patients with coronary heart disease, normal White and normal Bantu subjectss $\vec{\omega}$ (Lewis, 1958a). The lowest proportion of ue 0 saturated acids was found in the former grout, while the Bantu (who possess a strikingly iro munity to the disease), had significantly higher percentages of linoleic and arachidonic acids.

The formation of cholesterol deposits in the $\frac{0}{\circ}$ aortae of animals fed this sterol is retarded by simultaneous administration of unsaturated fats (Kritchevsky, 1954; Peiffer and Lundberg, 1957). 3 Another important experiment by Kritchevsky年 (1956) was to feed rabbits a diet containing choles-terol and a fatty acid with either two, one or no윽 double bonds. The degree of cholesterol deposition in the aorta was least when the acid with two 3 double bonds was fed. This acid was not linoleici acid but an isomer possessing no essential fatty acid activity. If this observation is confirmed and extended, it would seem that the action of un-? saturated fatty acids on cholesterol metabolism is not related to their behaviour as essential fatty acids in animal nutrition.

\section{The Unsaponifiable Fraction of Fats}

Natural fats contain not only triglycerides but ${ }_{\sigma}^{\omega}$ also a variable, small proportion of unsaponifiable material. This includes the tocopherols, potent anti-oxidants which protect highly unsaturated $\stackrel{\infty}{-}$ fatty acids from atmospheric oxidation. Of considerable interest are the sterols, cholesterol in ${ }^{\circ}$ animal fat and phytosterols such as $\beta$-sitosterol in $\mathbb{\mathbb { D }}$ the seed fats. Following the observation that $\stackrel{?}{\circ}$ $\beta$-sitosterol diminishes the hypercholesterolaemia $\underset{Q}{\stackrel{O}{Q}}$ 
and hepatic cholesterol deposition in chicks fed cholesterol (Rosenman et al., 1952), numerous experiments have been carried out on human subjects. Some studies have shown significant reduction in serum cholesterol (especially if initially high) when large doses of $\beta$-sitosterol are fed (Pollak, 1952; Beveridge et al., 1957; Barber and Grant, I955); other workers have found only minor changes (Steiner and Riley, 1955). It would appear from fractionation of certain vegetable oils that part of their effect in reducing the serum cholesterol is due to the unsaponifiable fraction (Beveridge et al., 1957; Wilkens, I958), but there is no doubt that potent activity is shown by pure preparations of esters of unsaturated fatty acids (Kinsell et al., 1958; Kinsell et al., 1956).

It is thought that $\beta$-sitosterol, and the similarly acting dehydrocholesterol interfere with intestinal absorption of cholesterol (Hernandez et al., I953; Nichols et al., 1953). These sterols are only slightly absorbed (Gould, I954), hence they may compete with cholesterol for the absorbing mechanism.

\section{Endocrine Factors in Cholesterol Metabolism}

Thyroid: Hypercholesterolaemia is usual in primary myxoedema and coronary heart disease is common. Yet cholesterol synthesis is subnormal in hypothyroidism, both in man (Kurland and Lucas, 1955) and in the rat (Rosenman et al., 1952); it is excessive in hyperthyroidism. Cholesterol turnover is low in myxoedema, as it is in xanthomatosis (Gould, 1958). In mice, thyroxine increases the rate of catabolism of cholesterol to acidic products (Weiss and Marx, 1955). It is conceivable that the hypercholesterolaemia in myxoedema is due to impaired catabolism of this sterol.

Recently, the synthetic thyroid hormone analogue triiodothyroacetic acid ('Triac') has been investigated in relation to lipid metabolism. In certain tissues oxidative deamination of triiodothyronine occurs, yielding Triac (Roche et al., 1955). Triac increases the oxygen consumption of thyroidectomized rats even more rapidly than its parent substance (Trotter, 1956). It remains to be established, however, that Triac is of physiological importance. In men with atherosclerosis and hypercholesterolaemia, it has the partly dissociated effects of reducing the serum cholesterol without obvious rise in B.M.R. (Oliver and Boyd, 1956), but with an increased incidence of effort angina (Oliver and Boyd, 1957).

Pancreas: Hypercholesterolaemia and hyperlipaemia are common in diabetes mellitus, often out of proportion to the disturbance in carbohydrate tolerance. The predisposition to atherssclerosis is well known. In the uncontrolled con- dition, particularly in the insulin-deficient type, there is an accumulation of acetyl-coenzyme A, the parent substance inter alia of the ketone bodies and cholesterol. Increased cholesterol synthesis occurs in the diabetic rat, and is reduced by fructose administration (Hotta et al., 1954). Glucagon diminishes the incorporation of acetate into cholesterol by liver slices (Hangaard and Stadie, 1953), though it elevates the serum cholesterol slightly (Oliver and Boyd, 1956). Alloxan diabetes, like hypothyroidism, accelerates the appearance of the essential fatty acid deficiency syndrome in the rat (Peifer and Holman, 1955); this would appear to be due to the hypercholesterolaemia increasing the demand for unsaturated fatty acids with which the plasma cholesterol is esterified.

Adrenal Cortex: Hypofunction leads to a reduction in serum-cholesterol and serum-phosphatide levels (Di Luzio et al., 1954; Selye, 1949*) Cortisone, prednisone and ACTH conversely, elevate cholesterol levels, chiefly affecting the unesterified fraction (Wang et al., 1955). In atherosclerotic, hypercholesterolaemic men, however, cortisone reduces the serum cholesterol (Oliver and Boyd, 1956). In large doses this hormone accelerates the clearance of postprandial lipaemia (Constantinides et al., 1957). In cholesterol-fed rabbits, cortisone further elevates the serum cholesterol but does not increase arterial lipid deposition; possible explanations include diminution of endothelial permeability (Wang et al., 1954). ACTH increases hepatic cholesterol synthesis (Rosenman et al., 1952) but ACTH and cortisone do not affect cholic acid secretion, i.e. cholesterol catabolism (Rosenman et al., I952).

Pituitary: Hypophysectomy diminishes cholesterol synthesis in the rat (Tomkins et al., 1952). Growth hormone (prepared from non-human sources presumably) did not affect the serum lipids of two normal subjects (Oliver and Boyd, 1956).

Sex Hormones: Coronary heart disease is infrequent in premenopausal women, while castration hastens the development of atheroma in women but retards it in men. The serum-cholesterol and phosphatide levels rise during pregnancy and vary during the menstrual cycle. Women have higher $\alpha$-lipoprotein and lower $\beta$-lipoprotein levels than age-matched men (Barr et al., 1952). It is thus clear that cholesterol metabolism is profoundly influenced by the sex hormones. Species differences and variations in dosage have obscured the interpretation of much experimental work. Thus oestrogens reduce aortic cholestrol deposition in rabbits fed this sterol (Ludden et al., 1942), but in large doses produce lipaemia in rats (Loeb, 1942) and lipid deposits in the 
chick aorta (Horlick and Katz, 1948). In men with hypercholesterolaemia and coronary heart disease, small doses of oestradiol reduce the serumcholesterol level and the $\beta$-lipoprotein cholesterol (Oliver andBoyd, 1956). In a recent study on normal and hypogonad subjects by Furman et al. (1958), sex hormones had little effect on total cholesterol and phosphatide levels; but oestrogen reduced $\beta$-lipoprotein and increased $\alpha$-lipoprotein concentrations while androgens had the converse effects. Oestrogens have been reported to decrease (Tomkins et al., 1952) and to increase (Fillios et al., 1958) hepatic cholesterol synthesis. They reduce the rate of clearance of postprandial lipaemia (Constantinides $e t$ al., 1957). Addition of androgen or oestrogen to serum in vitro does not alter its lipid or lipoprotein concentrations (Furman et al., 1958).

\section{Conclusion}

Biochemists and clinicians have much cause for satisfaction in having accumulated so great a body of information on cholesterol metabolism, largely in the past decade. It is hoped that the near future will bring a trend towards integration of this mass of data, in the form of unifying concepts which would facilitate the clinical application of this new knowledge.

\section{Summary}

The probable functions of cholesterol have been outlined, and its transport and distribution described. Absorption, synthesis, catabolism and excretion of this sterol are the main factors determining the magnitude of the cholesterol pool, and these topics are dealt with in turn. The effect of dietary factors on cholesterol metabolism (particularly the influence of unsaturated fatty acids) are reviewed, and a final section comments on the role of the endocrine organs in regulating lipid metabolism.

\section{BIBLIOGRAPHY}

ACHAYA et al., cited by DEUEL, H. J., Jnr. (1955), Fed. Proc., I4, 639.

AFTERGOOD, L., DEUEL, H. J., Jnr., and ALFIN-SLATER, R. B. (1957), $\mathscr{f}$. Nutr., 62, 1 29.

AHRENS, E. H., Jnr. (1957), Amer. F. Med., 23, 928.

ALFIN-SLATER, R. B., AFTERGOOD, L., WELLS, A. F., and DEUEL, H. J., Jnr. (1954), Fed. Proc., 13, 174.

ANDERSSON, N., and FAWCETT, B. (1950), Proc. Soc. exp. Biol. (N.Y.), 74, 768.

ANFINSEN, C. B. (1954), in Symposium on Athersclerosis Nat. Acad. of Science of U.S., Washington.

BARBER, J. M., and GRANT, A. P. (1955), Brit. Heart F., 17, 296. BARR, D. P., RUSS, E. M., and EDER, H. A. (1952), Trans. Ass. Amer. Phys., 65, 102.

BERGSTROM, S. (1952), Kgl. Fysiograf. Sallskap. Lund., Forh., 22, 91 .

BERGSTROM, S., and BORGSTRÖM, B. (1956), Ann. Rev. Biochem., 25, 177.

BEVERIDGE, J. M. R., CONNELL, W. F., and MAYER, G. A. (1957), Canad. F. Biochem. Physiol., 35, 257.

BIGGS, M. W., FRIEDMAN, M., and BYERS, S. O. (1951), Proc. Soc. exp. Biol. (N.Y.), 78, 641 .

BLOCH, K. (I95I), ' Recent Progress in Hormone Research,' 6, II I.
BLOCH, K., BERG, B. N., and RITTENBERG, D. (1943), F. biol. Chem., 149, 5 I I.

BLOOR, W. R. (1940), Ibid., 132, 77. BUCHER, N. L. R., and McCARRAHAN, K. (1955), Fed. Proc.,

BURR, G. O., and BURR, M. M. (1929), f. biol. Chem., 82, 345. C BRONTE-STEWART, B., ANTONIS, A., EALES, L., and BROCK, J. F. (1956), Lancet, i, 521 .

BYERS, S. O., and FRIEDMAN, M. (1958), Proc. Soc. exp. Biol.

(N.Y.), 98, 523 .
BYERS, S. O., FRIEDMAN, M., and GUNNING, B. (1953), Amer. F. Physiol., 175, 375.

CONSTANTINIDES, P., CAIRNS, A., and SO, Y. (1957), $\frac{\bar{\sigma}}{\bar{T}}$ Canad. F. Biochem. Biophys., 35, 503.

COOK. R. P., EDWARDS, O. C., RIDDELL, C., and $\varrho$

THOMSON, R. O. (1955), Biochem. F., 61, 676.
COON, M. J. (1955), Fed. Proc., 14, 762.

CORNFORTH. J. W., CORNFORTH, R. M., POPJAK, G., and $\overrightarrow{0}$ GORE, I. Y. (1958), Biochem.., 69 , 146.

CORNFORTH, J. W., and POPJAK, G. (1958), Brit. med. Bull., I4, 22 I.

CURRAN, G. L. (1956), Amer. Pract., 7, 1412.

DEUEL, H. J., Jnr. (1955), Fed. Proc., 14, 639.

DI LUZIO, N. R., SHARE, M. L., and ZILVERSMIT, D. B. (1954), Metabolism, 3, 424.

ECKLES, N. E., TAYLOR, C. B.. CAMPBELL, D. T., and $\omega^{\omega}$ GOULD, R. G. (1955), Ұ. Lab. clin. Med., 46, 359.

FEIGENBAUM, L. BYERS. S. O., and FRIEDMAN, M. (1954), $\vec{A}$ Proc. Soc. exp. Biol. (N.Y.), 85, 530.

FREDRICKSON, D. S. (1956), $\mathcal{f}$. biol. Chem., 222, 109. iv

FILLIOS, L. C., KAPLAN, R., MARTIN, R. S., and STARE, F. J. (1958), Amer. F. Physiol., 193, 47.

FRIEDMAN, M., and BYERS, S. O. (1955), f. clin. Invest., 34, 을 1369. FRIEDMAN, M., BYERS, S. O., and MICHAELS, F. (1951),
Amer. F. Physiol., 164, 789.

FRIEDMAN, M., BYERS, S. O., and ST. GEORGE, S. (1956), 을. Ann. Rev. Biochem., 25, I77. FRIEDMAN, M., ROSENMAN, R. H., and BYERS, S. O. (195\$t, $\overrightarrow{0}$
尹. Gerontol., 10, 60 .

FURMAN, R. H., HOWARD, R. P., NARCIA, L. N., a KEATZ, E. C. (1958), Amer. F. Med.; 24, 80.

GARDNER, J. A., and GAINSBOROUGH, H. (r928), Biochem. 22, 1048. GORDON, H., LEWIS, B., EALES, L., and BROCK, J. F.
(r957a), Nature, r80, 923.

GORDON, H., LEWIS, B., EALES, L., and BROCK, J. F. ̊ (1957b), Lancet, ii, 1299.

GOULD, R. G. (1954), in Symposium on Atherosclerosis, Nat. Acad. of Science of U.S., Washington.

GOULD, R. G. (1954), Circulation, 10, 589.

GOULD, R. G. (1958), in Conference on Hormones in Atherosclerosis, cited in Brit. med. F., i, 1059.

GOULD, R. G., TAYLOR, C. B., HAGERMAN, J. S., WARNER, I., and CAMPBELL, D. J. (I953), F. biol. Chem., 201, 5 I 9.

HANGAARD, E. S., and STADIE, W. C. (1953), Ibid., 200, 753.

HANSEN, A. E., ADAM, D. J. D., WIESE, H. F., BOELSCHE, R. N., and HAGGARD, M. E. (I958), Fourth International Conference on Biochemical Problems of Lipids, held at Oxford, 1957.

HEARD, R. D. H., BLIGH, E. G., CANN, M. C., JELLNICK, P. H., O'DONNELL, V. J., RAO, B. G., and WEBB, J. L. O (1956), 'Recent Progress in Hormone Research,' 12, 45.

HEARD, R. D. H., and O'DONNELL, V. J. (1954), Endocrinology, 54, 209.

HECHTER, O., and PINCUS, G. (1954), Physiol. Rev., 34, 459.

HELLMAN, L., ROSENFELD, R. S., INSULL, W., and $O$ AHRENS, E. H., Jnr. (1957), 'ł. clin. Invest., 36, 898.

HERNANDEZ, H. H., PETERSON, D. W., CHAIKOFF, I. L., and DAUBEN, W. G. (1953), Proc. Soc. exp. Biol. (N.Y.), の 83, 498.

HILL, R., BAUMAN, J. W., and CHAIKOFF, I. L. (1955), 今ั ORLICK, L., and KATZ, L. N. (1948), F. Lab. clin. Med., 33, 733.

HOTTA, S., HILL, R., and CHAIKOFF, I. L. (1954), f. biol.ర Chem., 206, 835 .

JAMES, A. T., LOVELOCK, J. E., and WEBB, J. (1957), $\frac{\mathfrak{C}}{\mathbb{C}}$

KARVINEN, E., LIN, T. M., and IVY, A. C. (1954), Amer. $\mathcal{~} . \stackrel{\mathscr{D}}{?}$ Physiol., 179, 650.

KARVINEN, E., LIN, T. M., and IVY, A. C. (1957), f. appl. $\frac{T}{\bar{O}}$ Physiol., II, 143.

KELSEY, F. E., and LONGENECKER, H. E. (I94I), f. biol. Chem., 139, 727. 
KENDALL, F. (1958), in Conference on Hormones in Atherosclerosis, cited in Brit. med. F., i, 1059.

KEYS, A. (1952a), Circulation, 5, 115.

KEYS, A. (1952b), Voeding, 13, 539.

KEYS, A., MICKELSEN, O., MILLER, E. v. O., HAYES, E. R., and TODD, R. L. (1950), F. clin. Invest., 29, 1347.

KIM, K. S., and IVY, A. C. (1952), Amer. F. Physiol., 171, 302.

KINSELL, L. W., FRISKEY, R. W., MICHAELS, G. D., and BROWN, F. R., Jnr. (1956), Amer. Э. clin. Nutr., 4, 285.

KINSELL, L. W., MICHAELS, G. D., FRISKEY, R. W., and SPLITTER, S. (1958), Lancet, i, 334.

KRETCHMER, N., and BARNUM, C. P. (195I), Arch. Biochem. Biophys., 5I, $14 \mathrm{I}$.

KRITCHEVSKY, D., MOYER, A. W., TESAR, W. C., LOGAN, J. B., BROWN, R. A., DẢVIES, M. C., and COX, H. R. (1954), Amer. F. Physiol., 178, 30 .

KRITCHEVSKY, D. (1956), Amer. F. Path., 185, 279.

KURLAND, G. S., and LUCAS, J. L. (1955), F. clin. Invest., 34, 947.

LEWIS, B. (1958a), Lancet, ii, 71 .

LEWIS, B. (1958b), Ibid., i, 1090.

LINDHOLM, H. (1956), Scand. F. clin. Lab. Invest., 8, supplement 23.

LIPSKY, S. R., HAAVIK, A., HOPPER, C. L., and MCDIVITT, R. W. (1957), F. clin. Invest., 36, 233.

LOEB, H. G. (1942), Proc. Soc. exp. Biol. (N.Y.), 49, 340.

LOVERN, J. A. (1954), 'The Chemistry of Lipids of Biochemical Significance,' p. 84, Methuen, London.

LUDDEN, J. B., BRUGER, M., and WRIGHT, I. S. (1942), Arch. Path., 33, 58.

McFARLANE, A. S. (1942), Nature, 149, 439.

MELNICK, D., and. DEUEL, H. J., Jnr. (1954), F. Amer. Oil Chemists' Soc., 31, 63.

MERRILL, J. M. (1958), Proc. Amer. Physiol. Soc., to be published.

MESSINGER, W. J., POROSOWSKA, Y., and STEELE, J. M. (1950), Arch. intern. Med., 86, 189.

MORRIS, M. D., CHAIKOFF, I. L., SELTZ, J. M., ABRAHAM, S., and FANSAH, N. O. (1957), f. biol. Chem., 224, 1039.

MORRISON, L. M. (1952), F. Lab. clin. Med., 39, 550.

NICHOLS, C. W., SIPERSTEIN, M. D., and CHAIKOFF, I. L. (1953), Proc. Soc. exp. Biol. (N.Y.), 83, 756.

OLIVER, M. F., and BOYD, G. S. (1956), Lancet, ii, 1273.

OLIVER, M. F., and BOYD, G. S. (1956), Circulation, 13, 82.

OLIVER, M. F., and BOYD, G. S. (1957), Lancet, i, 124.

ONCLEY, J. M., GURD, F. R. N., and MELIN, M. (1950), f. Amer. chem. Soc., 72, 458 .

ONCLEY, J. L., MELIN, M., RICHEST, D. A., CAMERON, J. W., and BROSS, P. M., Jnr. (I949), Ibid., 7I, $54 \mathrm{I}$.

PAGE, I. H., LEWIS, L. A., and PHAHL, G. (1953), Circulation Res., 1,87 .

PEIFFER, J. J., and HOLMAN, R. T. (1955), Arch. Biochem. Biophys., 57, 520.

PEIFFER, J. J., and LUNDBERG, W. O. (1957), Fed. Proc., I6, 232.

PETERSON, D. W. (1951), Proc. Soc. exp. Biol. (N.Y.), 78, 143.
POLLAK, O. J. (1952), Circulation, 6, 459.

REID, M. E. (1955), Fed. Proc., $14,448$.

REISER, R. (1950), f. Nutr., 42, 319.

RIECKENHOFF, I. G., HOLMAN, R. T., and BURR, G. O. (1949), Arch. Biochem., 20, 331.

ROBERTS, S., and SZEGO, C. M. (1955), Ann. Rev. Biochem., 24, 543 .

ROBINSON, D. S. (1955), Quart. F. exp. Physiol., 44, 112.

ROCHE, J., MICHEL, B., JOUAN, P., and WOLF, W. (1955), C. R. Acad. Sci., 241, 1880 .

ROSENBERG, H. R. (1945), 'Chemistry and Physiology of the Vitamins,' Interscience, New York and London.

ROSENMAN, R. H., FRIEDMAN, M., and BYERS, S. O. (1952), F. clin. Endocr. and Metab., 12, 1287.

ROSENMAN, R. H., FRIEDMAN, M., and BYERS, S. O. (I952), Endocrinology, 51, 142.

ROSENMAN, R. H., FRIEDMAN, M., and BYERS, S. O. (r957), F. clin. Invest., 36,1558

RUSS, E. M., RAYMUNT, J., and BARR, D. P. (1956), Ibid., 35,133 .

RUTSTEIN, D. D. INGENITO, E., CRAIG, J. M., and MARTINELLI, M. (1958), Lancet, i, 545.

SCHWENK, E., ALEXANDER, G. H., and FISH, C. A. (1955), Arch. Riochem. Biophys., 58, 37.

SELYE, H. (1949), 'Textbook of Endocrinology,' and edition, Acta Endocrinologicas, Montreal.

SIPERSTEIN, M. D., and MURRAY, A. W. (1955), F. clin. Invest., 34, 1449.

SMITH, A. L., HANK, R., and TREADWELL, C. R. (1958), Amer. F. Physiol., 193, 34 .

SRERE, P. A., CHAIKOFF, I. L., TREITMAN, S. S., and BURSTEIN, L. B. (1950), f. biol. Chem., 182, 629.

STEINER, A., and RILEY, E. P. (1955), Circulation, 12, 483.

STONE, D., and HECHTER, O. (1954), Arch. Biochem. Biophys., 5I, 457.

TAVORMINA, P. A., GIBBS, M. H., and HUFF, J. W. (1956), F. Amer. chem. Soc., 78, 4498.

TOMKINS, G. M., CHAIKOFF, I. L., and BENNETT, L. L. (1952), अ. biol. Çhem., 199, 543.

TROTTER, W. R. (1956), Lancet, i, 885.

UNGAR, F., and DORFMAN, R. I. (1953), f. biol. Chem., 205, 125.

van BRUGGEN, J. T., HUTCHENS, J. T., CLAYCOUMB, C. K., CATHEY, W. J., and WEST, E. S. (1952), Ibid., 196, 389.

WANG, C. I., BOSSAK, E. J., and ADLERSBURG, D. (1955), F. clin. Endocr. and Metab., 15,1308 .

WANG, C. I., SCHAEFER, L. E., and ADLERSBERG, D. (1954), Circulation, 10, 598.

WEISS, S. B., and MARX, W. (1955), f. biol. Chem., 213, 349.

WERTHESSEN, N. T., MILCH, L. J., RODMAND, R. F., SMITH, L.'L., and SMITH, E. C. (I954), Amer. F.' Physiol., 178, 23 .

WHITNEY, J., and ROBERTS, S. (1955), Ibid., 181, 446.

WILKENS, J.'A. (1958), S. Afr. med. भ., 32, 85

WOOD, J. D., and MIGICOFSKY, B. B. (1958), Canad. $\mathcal{F}$. Biochem. Biophys., 36, 433 .

\section{RUTHIN CASTLE, NORTH WALES}

A Clinic for the diagnosis and treatment of Internal Diseases (except Mental or Infectious Diseases). The Clinic is provided with a staff of doctors, nurses, technicians, modern Radiological and Physiotherapy departments.

The surroundings are beautiful. The climate is mild. There is central heating throughout. The annual rainfall is 30.5 inches, that is less than the average for England.

The Fees are inclusive and vary according to the room occupied. 